Journal of Health Promotion and Behavior (2018), 3(2): 94-99

https://doi.org/10.26911/thejhpb.2018.03.02.02

\title{
Parental Communication, Peer Role, and the Contextual Effect of School on Safe Sex Behavior among Adolescents in Mojokerto, East Java
}

\author{
Feny Lianawati'), Argyo Demartoto²), Rita Benya Adriani3) \\ 1)Masters Program on Public Health, Universitas Sebelas Maret \\ 2)Masters Program in Sociology, Faculty of Social and Political Sciences, Universitas Sebelas Maret \\ 3)School of Health Polytechnics Surakarta
}

\begin{abstract}
Background: Globally, youth are particularly vulnerable to the negativeconsequences of sexual behavior, such as unwanted pregnancies, AIDS and other STDs. The importance of school contextual effects on health and well-being among young people is increasingly recognized. This study aimed to examine the effects of parental communication and peer role on safe sex behavior among adolescents in Mojokerto, East Java, with special consideration of the contextualeffect of school.

Subjects and Method: This was a cross-sectional study conducted at 15 senior high schools in Mojokerto, East Java, from April to May 2018.A sample of 200 students was selected by stratified random sampling.The dependent variable was safe sex behavior. The independent variables were parental communication and peer role. The data were collected by questionnaire and analyzed by a multilevel analysis.
\end{abstract}

Results: Parental communication role $(b=1.00 ; 95 \% \mathrm{CI}=-0.56$ to $1.44 ; \mathrm{p}<0.001)$ and peer role ( $b=0.84 ; 95 \% \mathrm{CI}=0.41$ to $1.27 ; \mathrm{p}<0.001$ ) positively affected safe sex behavior among adolescents. School had a contextual effect on safe sex behavior with ICC $=9.6 \%$.

Conclusion: Parental role and peer role positively affect safe sex behavior among adolescents. School has a considerable contextual effect on safe sex behavior.

Keywords: safe sex behavior, parental communication, peer role,multilevel analysis

Correspondence:

Feny Lianawati. Masters Program on Public Health, Universitas Sebelas Maret. Jl. Ir. Sutami No. 36A, Surakarta 57126, Central Java. Email: fenyliana188@gmail.com. Mobile:+6282143157071.

\section{BACKGROUND}

Adolescence is a period of transition from children to adults ranging from 10 years to 19 years. This period of adolescence will go through several stages in their life ranging from physical and sexual maturity, the stages towards social and economic independence to build identity, skills and ability to negotiate (abstract reasoning) for his adult life (World Health Organization, 2015).

Adolescence is a transitional period from childhood to adulthood in which many experience changes such as physical, psychological and social changes take place.
Physical changes will occur faster than psychological and social changes. Sexual hormones have begun to function in adolescents, causing teenagers to engage in sexual behavior (Mahmuda et al., 2016).

Risky behavior in adolescents refers to everything related to personality development and adaptation in adolescents. The prevalence of risky behavior in adolescents is increasing and the impact is also increasingly alarming (Montazeri et al., 2016). Knowledge and understanding of reproductive health is very necessary for adolescents (Farid et al., 2013). 
Factors that influence healthy sex behavior include knowledge/ information about reproductive health so that teenagers can understand about what they should do and what is inappropriate. Teenagers have the right to obtain information about reproductive health from trusted sources (Widyastuti et al., 2009), (Pratiwi, 2011).

Female sexual function is faster to mature than men. Biologically, men are easily aroused compared to women (Manlove et al., 2008). The role of good parental communication is the protection against risky sexual behavior (Schelar et al., 2011). Peer friends have an important role in the lives of adolescents in establishing adolescent reproductive health information and all sexual problems experienced.

The role of parental communication can lead to the closeness of parents with adolescents so parents can guide and direct their children to avoid risky sexual behavior. Adolescence life requires monitoring from parents and knowledge of reproductive health in order to avoid risky sexual behavior which will ultimately have a negative impact on their life (Widyastuti et al., 2009).

Peers have a big influence on the formation of adolescent attitudes. It is because they prefer to gather with peers, and the ties in peer groups are very strong, in this period teenagers want freedom in doing sexual activities which sometimes will cause conflict in themselves which can result in anxiety and feeling guilty. Peers also have an important meaning in establishing reproductive health information and sexual problems faced and become one of the motivations in forming adolescent identity in conducting socialization (Farida et al., 2013).

The results of the 2012 Indonesian Youth Reproductive Health Survey (SKRRI) show that $29.5 \%$ of male adolescents and
$6.2 \%$ of female adolescents had touched or stimulated their partners. $48.1 \%$ of male adolescents and $29.3 \%$ of female adolescents have ever kissed on the lips, and $79.6 \%$ of male adolescents and $71.6 \%$ of women had held hands with their partners (Mahmudah, 2016). In 2015, in Mojokerto, within a period of one year, the number of student pregnancies reached 60 people consisting of 42 high school students, 12 junior high school students and 6 elementary school students. In addition, data from various sources states that $12.5 \%$ of the total KTD (pregnancy is not wanted) which occurs which is around 15,000 per year are students. Of the total cases that occurred, $85 \%$ of them are due to premarital sex, and the rest was due to rape victims. The causes of risky sexual behavior in adolescents include knowledge, gender, economic status, access to information, the role of communication between parents, peers (Lestary, 2007).

Lack of parental communication with their children influences the understanding of risky sexual behavior in adolescents which is very detrimental to adolescents and families, because in adolescence, it has an important role in development, namely cognitive development, social emotion, and sexuality. This is influenced by several factors such as culture, religion and correct information (Robi et al., 2012).

One of the government's efforts to reduce risky sexual behavior with the holding of the Youth Counseling Information Center (PIKR) program, aims to protect and prevent adolescents from engaging in unhealthy sexual behavior in reproductive health, preparing teenagers to undergo healthy reproductive health and being responsible for physical, psychological, and social preparation to get married and become a parent at a mature age (Ministry of Health, 2015). Based on the 
Journal of Health Promotion and Behavior (2018), 3(2): 94-99

https://doi.org/10.26911/thejhpb.2018.03.02.02

description above, researchers are interested in conducting a study under the issue of "Multilevel Analysis of the Role of Parents 'and Friends' Communication in Healthy Sexual Behavior in Adolescents in Mojokerto, East Java."

\section{SUBJECTS AND METHOD \\ 1. Study Design}

This was an analytic observational with a cross sectional design. The study was conducted at 15 senior high schools in Mojokerto, from May to June 2018.

\section{Populasi dan Samples}

The source population was senior high school students in Mojokerto, East Java. A sample of 200 students by stratified random sampling.

\section{Study Variables}

The dependent variable is healthy sexual behavior while the independent variables include the role of communication between parents and peers.

\section{Operational Definition of Variables} The role of parental communication was defined as the closeness of parents in resolving adolescent problems in which parents are the first source of education measured by using a questionnaire with a continuous scale for the sake of analysis which is changed into category of good or not good/poor.

Peers have a significant role in giving information and references for adolescents measured by using a questionnaire with a continuous scale for the benefit of analysis

Table 1. Univariate Analysis

\begin{tabular}{lcc}
\multicolumn{1}{c}{ Variable } & Frequency & (\%) \\
\hline Parental Communication Role & 96 & 48 \\
Good & 104 & 52 \\
Poor & & 48.5 \\
Peer Role & 97 & 51.5 \\
Positive & 103 & \\
Negative & & \\
\hline
\end{tabular}

which is changed to category of positive and negative.

Healthy sex behavior is the ability of a teenager to achieve physical, psychological and social well-being measured by using a questionnaire with a continuous scale for the sake of analysis which is changed to categorical healthy behavior and unhealthy behavior.

\section{Data Analysis}

Univariate analysis was used to see the frequency distribution and the percentage characteristics of the study subjects. Bivariate analysis was conducted to determine the relationship between healthy sex behavior in adolescents and independent variables using chi-square test and calculation of odds ratio (OR) with a confidence level (CI) of $95 \%$.

\section{Research Ethics}

The research ethical clearance was obtained from the Research Ethics Committee at Dr. Moewardi Hospital, Surakarta, Central Java, Indonesia. Research ethics included issues such as informed consent, anonimity, confidentiality, and ethical clearance.

RESULTS
1. Univariate Analysis
Table 1 showed that the adolescents who
have poor parental communication role
were $104(52 \%)$ and the adolescents with
good status were $96(48 \%)$. Negative peer
roles were $103(51.5 \%)$ and positive peer
roles were $97(48.5 \%)$.


Table 2. Bivariate Analysis

\begin{tabular}{|c|c|c|c|c|c|c|c|c|c|}
\hline \multirow{3}{*}{$\begin{array}{c}\text { Independent } \\
\text { Variable }\end{array}$} & \multicolumn{4}{|c|}{ Behavior } & \multirow{2}{*}{\multicolumn{2}{|c|}{ Total }} & \multirow{3}{*}{$\mathbf{O R}$} & \multirow{3}{*}{$95 \% \mathrm{CI}$} & \multirow{3}{*}{$\mathbf{p}$} \\
\hline & \multicolumn{2}{|c|}{ Healthy } & \multicolumn{2}{|c|}{ At Risk } & & & & & \\
\hline & $\mathbf{N}$ & $\%$ & $\mathbf{N}$ & $\%$ & $\mathbf{n}=\mathbf{2 0 0}$ & $\%$ & & & \\
\hline \multicolumn{10}{|c|}{ Communication } \\
\hline Good & 91 & 85 & 5 & 44.6 & 96 & 100 & \multirow[t]{2}{*}{100} & 35.1 & \multirow[t]{2}{*}{$<0.001$} \\
\hline Poor & 16 & 15 & 88 & 94.6 & 104 & 100 & & to 284.9 & \\
\hline \multicolumn{10}{|l|}{ Peer Role } \\
\hline Positive & 94 & 87.9 & 3 & 32.3 & 97 & 100 & \multirow[t]{2}{*}{216.9} & 59.8 to & \multirow[t]{2}{*}{$<0.001$} \\
\hline Negative & 13 & 12.1 & 90 & 87.9 & 103 & 100 & & 786.6 & \\
\hline
\end{tabular}

Table 3. The Results of Multilevel Analysis

\begin{tabular}{|c|c|c|c|c|}
\hline \multirow{2}{*}{ Variable } & \multirow{2}{*}{ b } & \multicolumn{2}{|c|}{ 95\% CI } & \multirow[b]{2}{*}{$\mathbf{p}$} \\
\hline & & Lower Limit & Upper Limit & \\
\hline \multicolumn{5}{|l|}{ Fixed Effect } \\
\hline Parental Communication Role & 1.00 & 0.56 & 1.44 & $<0.001$ \\
\hline Peer Role & 0.84 & 0.41 & 1.27 & $<0.001$ \\
\hline \multicolumn{5}{|l|}{ Random Effect } \\
\hline Var (Constants) & 7.66 & $7 \cdot 48$ & 7.85 & $<0.001$ \\
\hline Observation Score $=200$ & & & & \\
\hline School Score $=15$ & & & & \\
\hline Likelihood Ratio Test $=-246.3$ & & & & \\
\hline $\mathrm{ICC}=9.6 \%$ & & & & \\
\hline
\end{tabular}

\section{Bivariate Analysis}

Bivariate analysis described the relationship between independent variables (parental communication role and peer role) with dependent variable (safe sex behavior among adolescents). The results of bivariate analysis can be seen in table 2.

\section{Multilevel Analysis}

In table 3 , the score of $\mathrm{ICC}=9,6 \%$. This indicator showed that the school in each level/strata did not have contextual effect on safe sex behavior among adolescents in High School. The lack of school activeness in arranging YCIC (Youth Counseling Information Center) lead to lack of contextual effect on adolescents at the community level.

However, from the results of individual levels, it can be concluded that there was a multivariate effect about the effect of independent variables, namely the role of parental communication and peer role to one dependent variable which was healthy sex behavior among adolescents.

There was a significant effect between the role of parental communication and safe sex behavior in adolescents. Good parental communication role would increase safe sex behavior in adolescents $(b=1.00 ; 95 \% \mathrm{CI}=-0.56$ to $1.44 ; \mathrm{p}<0.001)$. There was an effect of peer role on safe sex behavior which was statistically significant. Peers who behave positively would increase safe sex behavior in adolescents $(b=0.84$; 95\% $\mathrm{CI}=0.41$ to 1.27 ; $\mathrm{p}<0.001$ ).

\section{The effect of parental communica-} tion role on safe sex behavior

There was a significant effect between the role of parental communication and safe sex behavior in adolescents. Good parental communication role increased safe sex behavior in adolescents. The result of this study was in line with a study by Hentges et al. (2017) and Sekarrini et al. (2011), which stated that the role of parental communica- 
tion has an effect on safe sex behavior in adolescents.

The role of parental communication could affect safe sex behavior in their children, because family was the main aspect to determine the development of adolescents (Hentges et al., 2017). Open communication between parents and their children would lead to the closeness of parents and their children, so that adolescents could share the youth problems that they experienced with their parents and they could get the right information about safe sex behavior in living their lives, adolescents would also know the good things or things that they have to avoid.

The result of this study was in line with a study by Astirin et al. (2016). Communication with parents affected risky sexual behavior $(b=-0.24 ; 95 \% \mathrm{CI}=-0.04$ to $-0.01 ; p=0.025$ )

\section{The effect of peer role on safe sex behavior}

There was an effect of peer role on safe sex behavior which was statistically significant. Peers who behave positively would increase safe sex behavior in adolescents. The result of this study was in line with a study by Sohrabivafa et al. (2017), Ngawu et al. (2015), Pokhrel et al.(2017), which stated that peer role has an effect on safe sex behavior in adolescents.

Peers have an important role in adolescent behavior, information about reproductive health which was gained from peers encouraged the adolescents to determine their attitudes in interacting. Peers also became one of the motivations in the formation of adolescents' identity in conducing socialization, especially when having relationships with the opposite sex, and also as one of the information sources about reproductive health.

The result of this study was in line with a study by Wardhani et al., (2017), with the statistics $(\mathrm{b}=0.06 ; \mathrm{SE}=0.03 ; \mathrm{p}=$ 0.042).

\begin{tabular}{l}
\hline REFERENCE \\
\hline Astirin OP, Dharmawan R (2016). Asso- \\
ciation between Self-Esteem, Self- \\
Efficacy, Peers, Parental Controls and \\
Sexual Behavior in Adolescents at \\
High School, Surakarta. 1: 46-53. \\
Hentges RF, Shaw DS, Wang M (2017). \\
Early childhood parenting and child \\
impulsivity as precursors to aggress- \\
ion, substance use, and risky sexual \\
behavior in adolescence and early \\
adulthood. 1-15.doi: 10.1017/So9545- \\
79417001596.
\end{tabular}

Lestary H (2007). Perilaku Berisiko Remaja Di Indonesia Menurut Survey Kesehatan Reproduksi Remaja Indonesia (SKRRI) Tahun 2007 Young Adults Risk Behavior by Indonesia Young Adult Reproductive Health Survey. pp. 136-144.

Mahmudah U, Cahyati WH, Wahyuningsih AS (2013). Jurnal Kesehatan Masyarakat, Jurnal Kesehatan Masyarakat, 8(2): 113-120. doi: ISSN 1858-1196.

Manlove BJ, Terry-humen E (2008). Sexual And Reproductive Health Behaviors Among Teen And Young Adult Men: A Descriptive Portrait.

Montazeri S, et al. (2016). Determinants of Early Marriage from Married Girls' Perspectives in Iranian Setting: A Qualitative Study. Hindawi Publishing Corporation. doi: 10.1155/2016/8615929.

Pokhrel P, et al. (2017). IndividualismCollectivism, Social Self-Control and Adolescent Substance Use and Risky Sexual Behavior, Substance Use \& Misuse. Taylor \& Francis, 1-11. doi: 10.1080/10826084.2017.1392983.

Pratiwi NL (2011). Hiv-Aids Dan Perilaku Seks Tidak Aman Di Indonesia. 
Robi A, Rahmaniati M (2012). Determinan Perilaku Seksual Berisiko Pada Remaja di Indonesia Tahun 2010 2012. Analisis Data Survey Rencana Pembangunan Jangka Menengah Nasional Remaja BKKBN 2012(2011).

Schelar E, Nicole R, Scott ME. Risky Adolescent Sexual Behaviors and Reproductive Health in Young Adulthood. doi: $10.1363 / 4311011$.
Sohrabivafa M, et al. (2017). Prevalence of Risky Behaviors and Related Factors among Students of Dezful. 188-193.

Wardhani Y, Tamtomo D, Demartoto A (2017). Effect of Sexual Knowledge and Attitude, Exposure to Electronic Media Pornography, Peer Group, and Family Intimacy, on Sexual Behaviors among Adolescents in Surakarta, 2: 138-147. 